УДК 7.034(410)

ББК 85.03

DOI:10.18688/aa155-4-47

Bernhard Hollick

\title{
The Poet as a Saint: The Caxton Master's Portrait of Ovid and Its Literary Background
}

The degree to which Ovid's Metamorphoses have inspired literature and art from antiquity to today can hardly be overestimated [cfr. 27]. However, not only the mythical narratives awoke the imagination of the artists. The poet himself was depicted in countless portraits and sculptures. They are concerned with more than with Ovid as a person alone. In a condensed way they comment on how his poetry was understood in the course of the centuries.

A remarkable example can be found in William Caxton's Middle English translation of the Ovide moralisé en prose (OMP). The text survived only in two manuscript volumes: Cambridge, Magdalene College, Old Library, F.4.34 (book I-IX) and Pepys Library, 2124 (X-XV). They were written by a professional scribe c. $1480^{1}$. At the beginning of each of the 15 books of the OMP there are spaces for illuminations, of which only four were realized: a portrait of Ovid as a frontispiece on f. 16r [Ill. 74], Phaethon's Fall on f. 39v, Cadmus on f. 71v, and the death of Pyramus on $\mathrm{f} .98 \mathrm{v}^{2}$ The artist who made the first three of them became known as the "Caxton Master"; he is considered to be one of the most talented English book painters of his time, as evidence from other manuscripts supports [36, pp. 1-2].

In the frontispiece, Ovid is depicted kneeling and praying in a bare room (which could be part of a church or monastery $)^{3}$. The crown of leaves on his head mark him as a poet laureate, but his posture and facial expression are deeply devotional. However, his object of adoration is not a pagan icon but an image of Christ. Several signs indicate that Ovid's pleas for inspiration have not fallen on deaf ears, namely Christ's graceful gestures, the strays of light falling from him onto the poet, and finally two books on the floor - the two volumes of the Middle English $O M P$.

\section{The Iconographic Tradition}

No comparable portrait of Ovid has come to us. And even if we consider that there may have been other examples now lost, the frontispiece is still unusual. The Caxton Master's anachronism is common in that period; ancient persons are regularly transferred into a contemporary

It is doubtful whether the scribe worked for Caxton, as Kathleen L. Scott [36, p. XI], thought; a recent study by Lotte Hellinga [19, pp.73-74] questions that he commissioned the manuscript or the illuminations.

2 Scott [36, p. 24], suggests that the reason for the missing illuminations is a disagreement between the patron and the artists.

For a detailed description cfr. [36, pp. 3-11]. 
context ${ }^{4}$. In a number of manuscripts, Ovid is depicted as a scholastic teacher, for example in a French copy of the OMP in Paris, BNF, fr. $137, \mathrm{f} .1 \mathrm{r}^{5} \mathrm{~A} 15^{\text {th }}$-century Italian statue, today in the Museo civico of his hometown Sulmona, shows him dressed like a Renaissance scholar. Some artists even choose to hint at Ovid's role in Christian culture: In Gotha, Forschungsbibliothek, memb. I 98, f. 1r, a copy of Pierre Bersuire's Latin Ovidius moralizatus (OML), the poet is drawn together with Thomas Waleys (to whom the OML was wrongly ascribed) and two angels, indicating the Christianization of Ovidian myth in the medieval moralisation [36, p. 10]. However, in none of them Ovid is actually a Christian. Rather, images of biblical figures and saints served as a model for the Caxton Master: In one of his other paintings in Oxford, Bodleian Library, Bodley 283, f. 1r, the posture of Moses receiving the Ten Commandments is strikingly similar to that of Ovid.

\section{That grete clerk Ovide: the Metamorphoses in France and England}

The lack of paintings resembling the portrait of Ovid as the frontispiece does not imply that the Caxton Master was not following any models. His work is an illustration to the OMP therefore, it depends on Caxton's translation and its literary context as much as on the iconographic tradition ${ }^{6}$. And indeed, medieval literature was a rich source of inspiration for the Caxton Master or his patron.

In biographical writing, the few facts known about the poet's life were completed by a vast amount of legendary material. Not all of these reports end well for the poet's soul [2, p. 272]. But at least some of them tell us about his conversion: according to a $13^{\text {th }}$-century legend in the Southern German manuscript Freiburg i. Br., Universitätsbibliothek, MS. 380, f. 1r, he was baptized by John the Apostle, first became bishop of Tomis and then a martyr, and was worshipped as St Naso [2, pp. 270-273].

Most of these accounts were merely anecdotal. But there is one exception: the hermetic $D e$ vetula, composed around 1250, probably by the French poet and scholar Richard de Fournival. This fictive autobiography describes Ovid's way from a youthful lover to a serious scholar whose devotion to study finally leads him to intuitive knowledge of Christian doctrine, even if he could not fully comprehend it. By combining poetry, science, and theology, De vetula reflects the way the Metamorphoses were read from 1100 onwards, despite the moral and religious concerns this particular work of Ovid raised ${ }^{7}$.

In $14^{\text {th }}$-century France, a group of texts, namely the moralisations of the Metamorphoses, surpassed the earlier commentaries both in quality and quantity. The key text is the Ovide moralisé $(O M)$, in which an anonymous poet re-narrates the whole Metamorphoses in 70,000 French verses and complements them with physical, historical, moral, and spiritual expla-

\footnotetext{
4 Panofsky [34, p. 84], speaks of a "principle of disjunction" between model and significance, theme and form.

$5 \quad$ On BNF, fr. 137 cfr. [5, pp. 46-47]. This manuscript was often considered as the French basis for Caxton's Middle English translation [33, p. 15, p. 22]; recent studies deny that claim [30, pp. 19-25].

$6 \quad$ Illustrating texts offered particular freedom in certain aspects [1, p. 351]: "[The illustrator's] work is conceived as an extension of the text and benefits from the greater latitude allowed to literary compositions." $7 \quad$ The earliest examples are Arnulf of Orleans's (d. 1260) commentaries [16] and John of Garland's (d. after 1272) Integumenta Ovidii [17], cfr. [11;20].
} 
nations [3, pp. 90-136]. It also inspired other writings: the OMP and Bersuire's $O M L$. In the latter, the integration of the Metamorphoses into a Christian cosmos of knowledge becomes particularly evident: even if the $O M L$ is often copied alone, it is not an independent work, but only book 15 of the Reductorium morale which also includes an allegorical encyclopedia and an exposition of the Holy Scripture ${ }^{8}$. Despite the similar titles, these are independent works with slightly different aims [14, pp. 278-279]. But they conform to each other in their ambitious attempt to interpret Ovidian myth systematically in the light of medieval religious and intellectual needs.

The French reception of Ovid had an immense influence in the Latin West, on courtly literature as well as on sermons, literary criticism, and even scholastic works. This is particularly true for England, where De vetula and the $O M L$ were read widely ${ }^{9}$. A home-grown classicism, for which Ovid was a major authority, paved the way for their success [cfr. 38]. The institutional background of this classicist movement was highly diverse: we find its followers in monasteries, schools, universities, and literary circles like Richard de Bury's. The variety of sources is accordingly large. Today, most attention is paid to poetry like Geoffrey Chaucer's Canterbury Tales or John Gower's trilingual work [cfr. 10; 18; 28]. But there is a significant amount of further material: glosses and commentaries, sermons, and - most surprisingly - scholastic treatises [cfr. 7; 42]. Thinkers like Robert Holcot and Thomas Bradwardine regularly refer to Ovid in the context of psychology, cosmology, and theology. Significant interaction is observable between the different kinds of texts, partly due to the fact that the same authors were active in several genres. For example, Holcot used Ovid in preaching and in his theological works [22, pp. 26-31]. The Metamorphoses were a repertory of examples for virtue and vice and a sourcebook for ancient philosophy and belief. Ovidian myth did not receive a Christian meaning in all cases. In Bradwardine's De causa Dei, the poet is counted among the Platonists [35, p. 108, p. 112]. But in both ways, the Metamorphoses became a regular authority in theological and pastoral discourses.

The French and the English tradition soon began to mix. The Oxford-educated Benedictine Thomas Walsingham, author of the Archana deorum, which is the oldest surviving commentary on the Metamorphoses from England, relies on an extensive mythographic corpus, including Bersuire [8, p. 853]. Given the role of Ovid in this French-English cultural encounter, it is no longer an expression of personal admiration when Chaucer spoke of him as a man of greet auctoritee [37, v. 2158] or Gower of that grete clerk Ovide [26, VIII 2266, cfr. 26, p. 83]. They were merely stating how the poet was considered in their time.

This historical setting constitutes the background of the Caxton Master's portrait ${ }^{10}$. Unsurprisingly, it incorporates the Christian reading of the Metamorphoses in the OMP. But it does so in a British context, in which Ovid had already become a regular authority before the influence of the new sources from France. It might therefore not have been an accident that the portrait was the work of an English artist and not of a French one.

\footnotetext{
For a careful analysis of Bersuire's approach to Ovid cfr. [32].

Despite the lack of a linguistic barrier in England, where Anglo-Norman still was the language of the social elites, there are very few signs of any use of the French version, the $O M$ and the $O M P[7, \mathrm{p} .188]$.

${ }_{10}$ This is not to say that there are no sources from other places, which baptize Ovid; however, this paper will rely mainly on texts from the cultural ambience of the portrait under investigation.
} 


\section{From the Ancient Pantheon to the Image of Christ}

The connection between the portrait and literature will become more evident when taking a closer look at some specific aspects. The scenery of Ovid praying and receiving inspiration from the biblical god is prefigured in the $O M P$ and other texts.

The idea of divine inspiration as such is the least surprising aspect of the portrait. Indeed, it is Ovid's own claim in the opening lines of the Metamorphoses [21, I 2-4, transl. by Hill, p. 13]:

(...) di coeptis (nam vos mutastis et illas)

adspirate meis primaque ab origine mundi

ac mea perpetuum deducite tempora carmen.

(Oh gods, for it was you that changed [the shapes], inspire what I have begun and from the first beginning of the world lead my song down to my own times.)

In ancient and medieval literature, it was common to open poetic works with an invocation of god(s), muses, or other higher beings. In many cases, this plea for help was not taken seriously but is just a literary play [25, pp. 22-37]. Yet, exactly because this plea for aspiration and guidance was so conventional, it is worth noting how much attention it gained in the manuscript of the Middle English OMP - from the Caxton Master, who choose it for his frontispiece, but also from the scribe, who pointed it out in a rubric title on f. 16v: How Ouyde at the begynnyng of his booke maketh Invocacion for helpe \& Dyuyne ayde. Obviously, Ovid's introductory words were no longer considered as a mere topos but taken seriously. This is entirely consistent with the increasingly theological reception of his poems. However, in order to close the gap between Ovid and the saints to which he is counted in the portrait, the Caxton Master goes one step further. From a medieval perspective, it was not problematic to assume that pagan writers unknowlingly possessed some kind of prophetic knowledge ${ }^{11}$. But in the portrait Ovid is actually Christian. His prayer is not directed to a pagan icon but to an image of Jesus. The ancient pantheon vanished in favour of the one Christian god. The Caxton Master thereby touches an aspect about which medieval readers often felt uncomfortable. Even the $O M$ is still apologetic about the poet's polytheism [12, I 107-110]:

Que que li païen creüssent,

Des dieus que pluisors en fussent,

Nous devons croire fermement

Qu'il n'est fors uns Dieus seulement.

(Although the pagans believed that there were several gods we have to believe firmly that there is only one God.)

Early on, medieval scholars tried to purge the Metamorphoses from paganism. This was relatively easy as long as they concentrated on isolated passages like the famous account of the creation of the world, where indeed only one god is mentioned as the opifex rerum [21, I 79]. They clearly benefited from the absence of articles in the Latin language; when Ovid speaks of deus, as far as grammar is concerned it is not clear if he means the one and only or just any god. Of course, readers had to skip over the description of the creator as just one of many gods $[21$, I 32].

11 The classical example is Virgil's $4^{\text {th }}$ ecloge, which was already in late antiquity understood as a prophetic anounciation of Christ [2, p. 59]. 
But later commentators where not satisfied with such selective readings. They instead tried to solve the tension between pagan and Christian beliefs with a theory of polytheistic speech. Like the OM, the OMP warns of polytheism, but it gives a hint that the gods that Ovid asks for inspiration are maybe just a rhetorical figure: The plural $d i$, gods, in the prologue of the Metamorphoses is explained as follows: in hys begynnynge called God in plurel nombre [30, p. 76]. The variety of Gods is just a kind of religious language, not an expression of polytheistic belief; in his other books, Ovid speketh of the vnyté of God and of hys sapience not comparable, and also of his prudence, whyche he calleth governeresse of the vniversalytaté [30, p. 73]. Later commentaries discuss the problem at greater length. Around 1410 Thomas Walsingham gives in his Archana deorum a reason why writers referred to god in plural [39, I 1, p. 4]:

Archana deorum detecturi fatemur in primis cum doctis philosophis non esse nisi unum deum celi et terre, rerum omnium visibilium et invisibilium creatorem. Qui pro multiplici dispositione qua regit mundum ab eisdem variis variisque vocabulis appellatur.

(In order to uncover the secrets of the gods we have to confess mainly together with the erudite philosophers, that there is only one god, the creator of heaven and earth, of all visible and invisible things. Because of the manifold disposition, by which he reigns the world, he is called by them with all kinds of different names.)

Ironically, this assumption is based on a thought adopted from ancient philosophy: the many gods are just names for different forces and manifestations of one single deity [39, I 1, p. 4]. Pagan myth can be thought of as a symbolic description of the effects god has as the first cause. This is not to say that Walsingham considered myth an adequate religious language. He recognized the practise of the ancient peasants and shepherds as a kind of religion since they worshipped their god-given skills - agriculture, for example - as deities [39, I 1, p. 5]. But he is utterly critical when it comes to the poets, whom he accuses of turning religion into superstition by giving fictitious names to these idolized skills and adding further personification of disreputable behaviour, such as voluptuousness [39, I 1, p. 5]. However, his assessment of poetry does not prevent him from reading the Metamorphoses as an allegorical collection of all kinds of moral, historical, scientific and even theological knowledge [6, pp. 200-205]. Even more, in the Prohemia poetarum, a survey on the lives and writings of ancient and medieval poets, he states that the Metamorphoses were written to convince readers that there is only one $\operatorname{god}[4$, p. 171]:

Intendit ergo Ovidius homines ab immoderato amore revocare temporalium ex exhortari ad summi dei cultum ostendendo stabilitatem caelestium et varietatem temporalium; et mutationes enumarare, ut per tot mutationum genera nobis inculcet quam nulla sunt haec transitoria et caduca.

(Therefore Ovid intends to recall the people from improper love to temporal things and exhort them to the worship of the highest god, by showing the stability of celestial and the variability of temporal things. And [he intends to] list the transformations in order to inculcate us by so many kinds of transformations that these changeable and perishable things are nothing.)

Walsingham's Ovid is an artful missionary who uses myth to lure his audience towards the highest god. Of course, Walsingham was fully aware that with this term, the poet was not referring to the biblical god. But other medieval Ovidians found a way to turn philosophical monotheism into Christian doctrine. St. Paul prepared a loophole while preaching at the Are- 
opag: the deus ignotus, which the apostle used as a point of contact with his pagan listeners, was identified with Ovid's god [41, Acts 27, 23]. This connection was not exclusively made in Late Medieval England. It was first mentioned by Conrad of Hirsau, a German Benedictine who died around 1150, in his Dialogus super auctores [23, p. 51]. However, the reasons by which it was established make the difference. Conrad suggested that Ovid found his highest god not only by philosophical means but partim ratione humana, partim revelatione divina [23, p. 52]. But he remains silent on how Ovid might have gained access to revelation. Here, English scholastics were more outspoken. Like Conrad, Bradwardine relied on St. Paul in order to justify a reference to Ovid and his extensive use of poetry in De causa Dei in general [35, p. 157]. But he has a much more precise idea about how the knowledge of revelation came to the Roman poet. He draws on hermetic accounts of a primordial wisdom that found their way from the Hebrew patriarchs and prophets into Indian, Persian, Greek, and Roman culture via Hermes Trismegistos, the king of Egypt, who was instructed by Moses [35, pp. 74-76]. Hermetism became popular in Oxford due to Roger Bacon [32; 31, pp. 221-223]. But in contrast to him, Bradwardine does not tell a history of decline [31, p. 223]. Rather, he aims at establishing a link between pagan literature and biblical revelation. Thereby, he suspends the boundary between the gods of Ovid and St Paul. From there it is not far the scenery of the Caxton Master's portrait.

To imagine Ovid as a saint was not just the exotic idea of an artist who tried to bridge the gap between his Christian beliefs and pagan poetry. In fact it is an incisive illustration of the late medieval reception of the Metamorphoses, which were assimilated to Christian culture. The way Ovid's poems were read affected his representation in book paintings. On the basis of the literary sources, it is no longer surprising that the Caxton Master depicted Ovid as a saint, but rather that it took so long before someone came up with that idea. His portrait shows that literary and iconographic traditions were not isolated from each other, but that at least some artists had a sound knowledge of the texts they were illustrating. In the case of the Middle English $O M P$, this leads to a harmonic picture: William Caxton certainly was a modernizer, but in many respects his taste of literature was rather conservative. He preferred a medieval French adaption to the Metamorphoses themselves. It is therefore quite fitting that his translation is illustrated with a frontispiece that is deeply rooted in traditions reaching back to older readings of Ovid's carmen perpetuum.

Title. The Poet as a Saint: The Caxton Master's Portrait of Ovid and Its Literary Background

Author. Bernhard Hollick - Ph. D., Postdoctoral Research Fellow. University of Cologne, Albertus-Magnus-Platz, 50923 Cologne. Germany. bhollick@uni-koeln.de

Abstract. The frontispiece of William Caxton's Middle English translation of the Ovide moralisé en prose in Cambridge, Magdalen College, Old Library, Ms. F.4.34, fol. 16r, shows Ovid as a Christian saint, praying to and receiving inspiration from an image of Christ. There is no similar picture in any other manuscript. However, the artist, who is usually referred to as the Caxton Master, could draw on a broad literary background: the text illustrated by him belongs to a group of sources from France, which offer Christian interpretations (the so-called moralisations) of the Metamorphoses. At the same time, the Caxton Master is rooted in a home-grown English classicism, which from 1300 onwards established Ovid as a major authority, as is evident by commentaries, sermons, and - most surprisingly - scholastics writings. This paper aims to shed light on this interaction of literature and art.

Keywords: Bersuire; Bradwardine; Caxton; frontispiece; Ovid; Ovide moralisé; portrait; Walsingham.

Название статьи. Поэт в образе святого: портрет Овидия работы «кекстонского мастера» - литературная подоплека. 
Сведения об авторе. Холлик Бернард - Ph. D., научный сотрудник. Университет Кёльна, Albertus-MagnusPlatz, Кёльн, Германия, 50923. bhollick@uni-koeln.de

Аннотация. На фронтисписе перевода Ovide moralisé en prose на среднеанглийский язык, изданного Уильямом Кекстоном (Cambridge, Magdalen College, Old Library, Ms. F.4.34, fol. 16r), изображен Овидий, представленный в облике христианского святого, обращающегося в молитве и вдохновляемого образом Христа. Такое изображение не встречается более ни в одном манускрипте. Тем не менее художник, известный как «кекстонский мастер», мог ориентироваться на многочисленные книжные образцы: проиллюстрированный им текст восходит к французским источникам, в которых содержатся христианские интерпретации (так называемые морализации) «Метаморфоз». В то же время творчество «кекстонского мастера» вырастает из местного, исконно английского классицизма, в котором Овидию начиная с 1300-х гг., как явствует из комментариев, текстов проповедей и - самое удивительное - трудов схоластов, отводилось весьма авторитетное место. Цель статьи состоит в том, чтобы осветить взаимодействие литературы и изобразительного искусства.

Ключевые слова: Пьер Берсюир; Томас Брадвардин; Уильям Кекстон; фронтиспис; Овидий; Ovide moralisé; портрет; Фрэнсис Уолсингем.

\section{References}

1. Allen Ch. Ovid and Art. The Cambridge Companion to Ovid. Cambridge, Cambridge University Press, 2002, pp. 336-367.

2. Bischoff B. Eine mittelalterliche Ovid-Legende. Historisches Jahrbuch, 1952, no. 71, pp. 268-273 (in German).

3. Blumenfeld-Kosinski R. Reading Myth. Classical Mythology and Its Interpretation in Medieval French Literature. Stanford, Stanford University Press, 1997. 314 p.

4. Cabral F. Th. (ed.). Thomas Walsingham. Prohemia poetarum. Lincoln, University of Nebraska, 1974. 204 p.

5. Cerrito S. L'Ovide moralisé en prose entre text et image: un livre illustré de la bibliothèque de Louis de Bruges (ms. Paris, BnF, fr. 137). Quand l'image relit le texte. Regards croisés sur les manuscrits médiévaux. Paris, Presses Sorbonne Nouvelle Publ., 2013, pp. 41-57.

6. Clark J. G. A Monastic Renaissance at St Albans. Thomas Walsingham and His Circle c. 1350-1440. Oxford, Clarendon University Press, 2004. 316 p.

7. Clark J. G. Ovid in the Monasteries: The Evidence from Late Medieval England. Ovid in the Middle Ages. Cambridge, Cambridge University Press Publ., 2011, pp. 177-196.

8. Clark J. G. Thomas Walsingham Reconsidered: Books and Learning at Late-Medieval St. Albans. Speculum, 2002, no. 77, pp. 832-860.

9. Clark J. G., Coulson F. T., McKinley K. L. (eds.). Ovid in the Middle Ages. Cambridge, Cambridge University Press Publ., 2011.372 p.

10. Cooper H. Chaucer and Ovid: A Question of Authority. Ovid Renewed. Ovidian Influences on Literature and Art from the Middle Ages to the Twentieth Century. Cambridge, Cambridge University Press Publ., 1988, pp. 71-81.

11. Coulson F. T. Ovid's Metamorphoses in the School Tradition of France, 1180-1400. Texts, Manuscript Traditions, Manuscript Settings. Ovid in the Middle Ages. New York, Cambridge University Press Publ., 2011, pp. 48-82.

12. De Boer C (ed.). Ovide Moralisé, 5 vols. Amsterdam, Johannes Müller Publ., 1915-1938. 374 p.; 394 p.; 303 p.; 478 p.; 429 p.

13. De Boer C. (ed.). Ovide Moralisé en prose. Amsterdam, North Holland Publishing Company, 1954. 407 p.

14. Dimmick J. Ovid in the Middle Ages. Authority and Poetry. The Cambridge Companion to Ovid. Cambridge, Cambridge University Press Publ., 2002, pp. 264-287.

15. Engels J. (ed.). Pierre Bersuire. Reductorium morale. Liber XV (Ovidius Moralizatus), 3 vols. Utrecht, Instituut voor Laat Latijn d. Rijksuniversiteit Publ., 1960-1966. 35 p.; 189 p.; 56 p.

16. Ghisalberti F. (ed.). Arnulf of Orléans. Allegoriae super Ovidii Metamorphosin. Arnolfo d'Orléans: un cultore di Ovidio nel XII secolo. Milano, Hoepli Publ., 1932, pp. 201-234.

17. Ghisalberti F. (ed.). John of Garland. Integumenta Ovidii. Messina, Casa Ed. Principato Publ., 1933. 79 p.

18. Harbert B. Lessons from that Great Clerk: Ovid and John Gower. Ovid Renewed. Ovidian Influences on Literature and Art from the Middle Ages to the Twentieth Century. Cambridge, Cambridge University Press Publ., 1988, pp. 83-97.

19. Hellinga L. William Caxton and Early Printing in England. London, British Library Publ., 2010. 212 p.

20. Hexter R. J. Medieval Articulations of Ovid's Metamorphoses: From Lactantian Segmentation to Arnulfian Allegory. Mediaevalia, 1988, no. 13, pp. 63-82.

21. Hill D. E. (ed.). Ovid. Metamorphoses, 4 vols. Warminster, Aris \& Phillips Publ., 1985-2000. 263 p.; 248 p.; 230 p.; 250 p.

22. Hoffmann F. Die theologische Methode des Oxforder Dominikanerlehrers Robert Holcot. Münster — Aschendorff, 1972. 454 p. (in German).

23. Huygens R. B. C. (ed.). Conrad of Hirsau. Dialogus super auctores. Brussels, Latomus Publ., 1955. 69 p.

24. Klopsch P. (ed.). Ps. Ovidius. De vetula. Leiden - Cologne, Brill Publ., 1967. 298 p.

25. Klopsch P. Einführung in die Dichtungslehren des lateinischen Mittelalters. Darmstadt, Wissenschaftliche Buchgesellschaft Publ., 1980. 194 p. (in German). 
26. Macaulay G. C. (ed.). John Gower. Confessio Amantis, 2 vols. Oxford, Clarendon Press Publ., 1901.519 p.; 655 p.

27. Martindale Ch. (ed.). Ovid Renewed. Ovidian Influences on Literature and Art from the Middle Ages to the Twentieth Century. Cambridge, Cambridge University Press Publ., 1988. 298 p.

28. McKinley K. L. Gower and Chaucer: Readings of Ovid in Late Medieval England. , Ovid in the Middle Ages. Cambridge, Cambridge University Press Publ., 2011, pp. 197-230.

29. Michel P. Vel dic quod Phebus significat dyabolum: Zur Ovid-Auslegung des Petrus Berchorius. Sinnvermittlung. Studien zur Geschichte von Exegese und Hermeneutik I. Zürich, Pano Publ., 2000, pp. 293-347 (in German).

30. Moll R. J. (ed.). William Caxton. The Booke of Ouyde Named Methamorphose. Toronto, PIMS Studies Publ., 2013. $625 \mathrm{p}$.

31. Molland G. Adressing Ancient Authority: Thomas Bradwardine and Priscia sapientia. Annals of Science, 1996 , no. 53, pp. 213-233.

32. Molland G. Roger Bacon and the Hermetic Tradition in Medieval Science. Vivarium, 1993, no. 31, pp. 140-160.

33. Norgaard H. Sankt Ovid. Tekstligt og billedmaessigt om Metamorfosernes forvandling. Fond og Forskning, 1963 , no. 10, pp. 7-26. (in Danish).

34. Panofsky E. Renaissance and Renascences in Western Art. Uppsala, Almquist \& Wiksells Publ., 1960. $242+52$ p.

35. Savile H. (ed.). Thomas Bradwardine. De causa Dei adversus Pelagium. London, Billius Publ., 1618, reprint Frankfurt a. M., Minerva Publ., 1964. 876 p.

36. Scott K. L. The Caxton Master and His Patrons. Cambridge, Cambridge Bibliographical Society Publ., 1976. 91 p.

37. Skeat W.W. (ed.). Geoffrey Chaucer. House of Fame. The Complete Works of Geoffrey Chaucer. London, Oxford University Press Publ., 1965, pp. 326-348.

38. Smalley B. English Friars and Antiquity in the Early Fourteenth Century. Oxford, Basil Blackwell Publ., 1960. 398 p.

39. Van Kluyve R. A. (ed.). Thomas Walsingham. Archana deorum. Durham (NC), Duke University Press Publ., 1968. $227 \mathrm{p}$.

40. Von Albrecht M. Vergil: Bucolica - Georgica - Aeneis. Eine Einführung. Heidelberg, Universitätsverlag Winter Publ., 2007. 235 p. (in German).

41. Weber R. (ed.). Biblia Sacra iuxta Vulgatam Versionem. Stuttgart, Deutsche Bibelgesellschaft Publ., 1994.1980 p.

42. Wenzel S. Ovid from the Pulpit. Ovid in the Middle Ages. Cambridge, Cambridge University Press Publ., 2011, pp. $160-176$. 